\title{
He Tamaiti Tapu - a Māori principle- based framework: Responsive caregiving in the early childhood context
}

Aotearoa New Zealand is the home to a world first bi-cultural early childhood curriculum, affectionately referred to as Te Whāriki (Ministry of Education, 2017). This is one of many initiatives engaged by the Ministry of Education to encourage Māori participation at this level of education in the hopes this would permeate throughout all levels of education. First hitting the scene in 1996, Te Whāriki became the standard whereby other indigenous cultures watched with eagerness for indicators of educational success. With Te Kohanga Reo firmly entrenched around the country and knowing its status as tipuna to Te Whāriki, it would seem reasonable they would also be watching with interest for similar signs of success.

Te Whāriki was built upon a curriculum weaving principles of whakamana or empowerment, kotahitanga or holistic development, whānau tangata or family and community, ngā hononga or relationships with the strands of mana atua or wellbeing, mana whenua or belonging, mana tangata or contribution, mana reo or communication and mana aoturoa or exploration. The principles are the fibres that held the teaching and learning components together.

Most centres around the country implemented the curriculum with its treaty-based principles as they interpreted it or felt the need. This was particularly the case if there if there was an absence of Māori staff, children or a teacher mainly 
driven to teach the curriculum as intended. Ritchie (2003) argued that the lack of benchmarks for implementing the curriculum was a factor and teachers possibly needed more than guiding principles. Ritchie (2010) further commented that teacher knowledge, commitment and level of confidence also factored into how the curriculum was implemented daily.

The Education Review Office (ERO) (1998) was disappointed with Te Whāriki's lack of direction for early childhood educators in implementing this bicultural curriculum and consequently produced two documents to counter the absence of benchmarks. They provided examples of Tiriti-based practices for teachers and educators with which to assist Māori children, and their whānau (family) succeed as Māori (2010, 2010a). The Ministry of Education has also produced exemplars of assessment of learning based in kaupapa Māori to guide educators with benchmarks (2009).

Roll forward twenty years, and Te Whāriki (Ministry of Education, 1996) has undergone a revision. Why was this necessary? Partly it was to address our ever-increasing multicultural society, but it also needed to reflect the political and educational shifts over the last two decades and respond to research, curriculum, pedagogy and practice (Ministry of Education, 2017, p. 2).

As I have laid the foundation for this literature review, one defining point has become apparent. Even though curriculum has been revised and shifts in focus concerning education, research and politics have occurred, what remains constant over this period is my principle-based practice in the field of infant and toddler pedagogy, care and education.

This literature review is based around a principle-based model of well-being. He Tamaiti Tapu, developed by the author. This model is child centred and focuses on the principles of mana, mauri, wairua and whakapapa, being underpinned by the notion of tapu as "being with potentiality for power... It is the sacred life force that reflects the state of the whole person (Mead, 2003, p. 32). The opening statement of the early 
childhood curriculum Te Whāriki supports Mead saying, "all children are born with immense potential" (Ministry of Education, 2017, p. 2) Each of these principles are innate gifts speaking to the regard and high esteem in which young children are held and assist in drawing out the potentiality of each child.

\section{He Tamaiti Tapu: A principle-based model of practice}

Ahakoa he iti, he pounamu. Be it ever so small, it is as precious as jade. This renowned whakatauki speaks of the most precious gemstone in Te Ao Māori, the jade. Pere (1997) sees a child in the same light as the jade, precious. Like Pere, the child is precious to me and sits at the heart of this principle-based model of practice, He Tamaiti Tapu. The child is represented in this model by a koru, symbolising new life, growth and potential. The koru becomes a perfect metaphor of a child when tapu is defined as "being with potentiality for power" (Mead, 2003, p. 32). Mead (2003) points to faith, or spiritual power as the most important element of tapu. Marsden (2003) adds to the meaning of tapu by defining this as holy or sacred. From these definitions comes an understanding of the high regard with which a child was held in Māori tradition. Loved and valued before conception, birth, and time itself (Reedy, 2013). This is evident in the practice of writing oriori for pēpi, a lullaby containing messages of familial links, gifts and skills held within DNA, and messages of love and anticipation of arrival for the unborn child. Reedy (2013) continues in this vein as he shares how babies were nurtured in ways ensuring optimal growth, survival, happiness, as their roles of importance were transferred through chants, karakia, and oriori. Like a precious seed, babies received all they would need to thrive. Pere (1997, p. 40) looked upon tapu as a "way of developing an appreciation and a respect for another human being, another life force".

When framed in this light my principle-based model of practice conveys a positive message of immense potential, immense power, and a deep abiding sense of the sacred nature 
of a baby. So, it becomes imperative that the elements, principles, values if you wish, of mana, wairua, whakapapa, and mauri surround this baby, as represented by the koru. The gifts of tapu and mana are closely linked, and the one is never without the other. Both Marsden (2003) and Mead (2003), point to tribal areas often interchanging the one for the other. Rameka (2015) shares how tapu is potential power, but mana is actual power. Often defined as "authority, control, influence, prestige, power, psychic force, effectual, binding, authoritative..." (Hemara, 2000, p.68), so it becomes imperative that I ask myself each day in what manner do I uplift the mana of each child. One of the most common practices of adults is to place babies into positions of submission which leave them vulnerable and dependent on others. The practice of 'tummy time' often advocated for by well-meaning health representatives as beneficial for strengthening babies neck muscles is a position of vulnerability. A shared principle of Pikler (1946) and Resources for Infant Educarers commonly known as RIE (1978), is that of free movement and entails never placing babies into positions they cannot get into on their own. If they cannot get into that position, they are unable to get themselves out of the position and are rendered powerless. If a baby is given time and space, they will eventually be able to roll onto their tummy and back again by themselves. Apart from diminishing the mana of a child with these actions neuroscience research over the past decade has linked free movement for babies directly impacting on children's language, literacy and numeracy acquisition and fluency (Brainwave Trust, 2015).

Barlow (1991) argues that all things animate and inanimate have a mauri and are therefore connected. Mauri is described as the life force, or energy, the living essence "through which mana flows and manifests itself" (Paul-Burke, 2011, p.14). Therefore, tapu and mana cannot be realised without mauri. Many things can happen throughout a day that can cause the mauri of a child to wax or wane. Pere (1997) asks some important questions of teachers and adults "How carefully 
do we feel for and consider the mauri of each child in our care? Have we done everything we can to build up that mauri, or do we damage it in a small way each day?" (p.12). Mana and mauri enhancing practices require small adjustments to ensure respectful responses. The simple practice of waiting for a baby to notice you and indicate their desire to interact by leaning toward you is the cue that they are ready to spend time with you. What generally happens is we see a baby and charge straight into their personal space and begin touching their face and making faces to elicit a response to fill our self-worth bucket. Often, we fail to see the initial startled response that elevates their heart rate and triggers their fight, flight or fright response. Another practice that is often not seen to be negative because we are helping a child is the wiping of their nose. An adult will see a runny nose, take a tissue and reach across the child to wipe their nose clean. Most children will protest. A mauri enhancing approach offered by RIE (1978) involves slowing down and involving children in care routines rather than doing the routine to them. This can be as simple as kneeling near the child with a tissue and waiting for them to turn to you. Now the opportunity has presented itself to wipe their nose with them. A simple statement of ...your nose needs a wipe and depending on their age they will take the tissue offered, or they might lean toward the tissue for you to wipe their nose. Either way, the child is the decision maker, they exercise their autonomy, their power and in the process their mauri is kept intact.

There are many ways throughout the day for children to be involved in their learning and development which is enhanced by this principle-based model of practice. The key to success for this model lies within the principles of mana atua, mana whenua and mana tangata. Each of these principles strengthens the identity of the child through relationships and ties to whakapapa, land, and resources endearing a deep sense of belonging and self-worth. This principle-based model derives from esoteric knowledge culturally situated in Te Ao Māori. It 
upholds ancient practices of child rearing form places of love, esteem, and honour (Mead, 2003) and serves as a tool for reclaiming our cultural ways of knowing, being, and doing. Mā te ahurei o te tamaiti e ārahi i ā tātou mahi. Let the uniqueness of the child guide our work (Ministry of Education, 2017, p. 63).

\section{Figure 1: He Tamaiti Tapu}

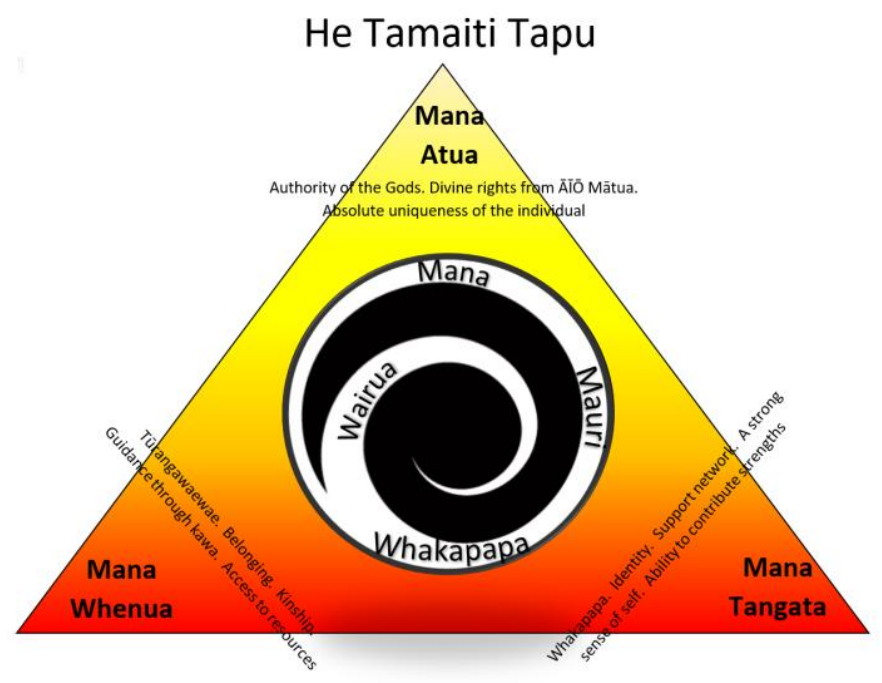

\section{Mana}

Often looked upon as meaning strength and power Hemara (2000) offers a definition that moves beyond the physical nature of mana and broadens understanding to other intangible elements of mana such as "authority, influence, prestige, psychic force, effectual, binding, authoritative... and take effect" (p. 68). One might pause and ask if an infant is capable of wielding influence, authority, prestige or psychic force? Pere (1997) challenges us to "feel for what this really means" (p. 14). Perhaps this example of everyday occurrence will demonstrate her influence and authority. As small as an infant is she can influence responses from the adults close by. Depending on 
whether the adult's response is timely, or if they have interpreted the call for help correctly, the infant may exercise her authority by increasing volume and changing tone. She may even call on her arms and legs to convey the message she needs assistance from an adult. Similarly, this baby girl can display her prestige and regard with which she is held by holding the gaze of an adult and smiling, thus affecting the prestige of the adult interacting with her. Pere (1997) mentions how this type of mana is "binding over others" (p. 14) and that other person knows so.

Marsden (2003) spoke of mana as a spiritual power delegated to human beings from the Atua to act on their behalf and under their will. He signified that human beings are the channels through which mana is received. In my place of practice, I rarely see this spiritual power but know if I were situated in a kohanga reo in the presence of kaumātua and tohunga this mana would be present. I am aware that children have access to this spiritual power of mana as they act as messengers for tupuna who have passed and I am confident I would recognise this type of mana and acknowledge this when it is experienced in the centre.

Rameka (2015) explained the close relationship between mana and tapu and how mana upholds a person's tapu. Mead's (2003) definition of mana spoke to children inheriting increments of mana from their parents' dependant on the parents' achievements and social status. If mana is an innate gift, then why should it be like this? Moreover, if so, should this determine the increment of love, care and attention I should give a child in my care? As a qualified teacher with a current practising licence, there is a code of standards I am mandated to uphold. Pere (1997) addressed the most important aspect of mana that is "mana atua - divine right from ĀĪO Mātua...This form of mana recognises the absolute uniqueness of the individual" (p.14). This definition sits comfortably within my principle-based model of well-being, and it also speaks to my teaching practice. Every single child in our centre is unique and 
so is their whānau. To be able to meet the needs of each child and especially infants we follow the Resources for Infant Educarers (1978) (RIE) approach, and offer continuity of schedules that mum and baby operate on to not confuse baby. This ensures what is happening at home happens in the centre. Each babies schedule differs from the other. Each baby is put to sleep as it would happen in their home. Some are rocked in our arms, some like to have a special song sung at sleep time, and some just prefer to be placed in their cot to drift off to sleep. When this is the sleep pattern of a baby, a teacher will sit in the room and wait for baby to fall asleep. In this manner, each experiences their absolute uniqueness.

\section{Mauri}

Mana and tapu cannot be realised without mauri because it is the life force, or energy, the living essence "through which mana flows and manifests itself" (Paul-Burke, 2011, p.14). It is through mauri we are connected to all living things (Barlow, 1991). Mauri "generates, regenerates and upholds creation...it is the bonding element that holds the fabric of the universe together" (Marsden, 2003, p. 174). These three sources support each other and reiterate the connection, therefore relationship we have with each other and all of creation. This denotes how I must be with children in my practice. Te Whāriki reminds kaiako to uphold the mana of a child by nurturing their mauri through warm reciprocal relationships and having them lead their learning (Ministry of Education, 2017). How does an infant lead his learning? Pikler (1946) will teach you how important uninterrupted time for play is to an infant. It is in these moments he will evolve through his initiative. No baby needs help to reach their milestones in life. As we refrain from teaching skills and activities, we invite infants to discover for themselves how their world operates and functions through the testing of their theories and ideas. As a teacher of infants, I can 
support with patience. This is one of the best practices in building up the mauri of a child.

Pere (1997) added to the conversation of being inter-related with everything in the universe by stating "everything in the universe is regarded as having the same divine right" (p. 12). She asks, "Do we feel for the mauri of the bush? Each Thursday we take a group of toddlers into Totara Park Forest for 3-4 hours. The same group of children with the same teachers for a semester. When a new group of children arrive, they are so excited, and they go crashing through the underbrush. It takes a few visits before we can settle them down, so they are mindful of all the plants and birds. When they are calm, we signal for them to watch and listen. In this state of being still, it is easy to feel connected to the mauri of the forest. This is when the children hear the birdsong and seek to find who is greeting them. It also when the children notice the leaves, feathers and flowers. Each trip to the forest brings treasures for our centre's collection of stones, grass, leaves and feathers. Through these practices, we are learning to walk with care upon Papatūānuku and within Tane. The forest is an excellent space for the mauri of children and teachers to be in a state of balance because we feel physically and socially well and enjoy optimal health (Mead, 2003). A child's mauri remains throughout their whole life until they leave this earth, unlike wairua which lives on after death.

\section{Wairua}

All children are born with wairua also known as spirit or soul (Mead, 2003). The spirit is immortal and continues to live even after our body returns to Papatūānuku. Wairua translates as two waters, denoting the spiritual and the physical make up of a person (Rameka, 2015). Whereas, Pere (1997) speaks to the two waters as positive and negative streams to consider, offering the thought that water can give life and can take life, so it is essential to keep a balance. Marsden (2003) alludes to this balance as human beings moving towards "perfect spirituality 
when consciousness has achieved omega point" (p. 46). Omega point seems to be a space where we, have changed our attitude towards ourselves and the environment. We must enhance and maintain the life support systems of Papatūānuku, treat her with love and reverence, and realise that we benefit from our relationship with Papatūānuku and therefore have stewardship of her. At our centre we actively recycle paper and cardboard. We limit the use of water during the summer months and have installed a particular tank to collect water for our gardens. We use only natural resources Mother Earth gifts us. This is how we enact our stewardship towards Papatūānuku.

I find within Te Whāriki (Ministry of Education, 2017) it speaks to the symbolic and spiritual meaning for Māori around the whāriki and raranga. As the work of weaving a mat requires skill, knowledge and time and the coming together of artisans the finished work is celebrated as a taonga. The mauri held within the whāriki is a collective mauri not only of the artisans but of the very fibres used to create the whăriki and serve to remind us of karakia offered when the harakeke was harvested. The Māori creative periods of Te Kore, Te Po, Te Ao Marama, the atua Māori and tipuna are given emphasis for teachers to value and enhance the teaching curriculum. These spiritual aspects denote whakapapa which enriches the identity, therefore, the wairua of each tamaiti. We are very careful when harvesting our harakeke for making putiputi so the plant will regenerate and continue to provide for our needs. Regarding whakapapa we have a whānau wall, pepeha sheets, and are celebrating every culture in our centre through song, dance and kai. In this manner, we are nurturing the identity and wairua of all our tamariki. Tacit knowledge and experiences in spiritual dealings guarantee our best interests are to the forefront of whatever we are doing because tipuna are guiding our footsteps. This is essential in the care and education of children and in my daily teaching practice safeguarding the child and myself from harm. What does wairuatanga, spirituality look like in the early childhood arena to me? Wairuatanga is many things and is 
woven across all principles in my model of practice for wellbeing. It speaks to mauri as I understand my connections to the whole universe. It is having knowledge and understanding of tangata whenua and their relationships to each other and the land. It is the principle of kaitiakitanga and walking with care upon Papatūannuku. It is nurturing Te Ira Atua, the divine spark of the child and ensuring mana is intact with every interaction (Ministry of Education, 2017). It is about understanding how wairua and whakapapa are essential to our well-being and holistic development.

\section{Whakapapa}

Whakapapa connects a person to the creation of the world and "Informs the genealogical relationships and provides the foundation for inherent connectedness and interdependence of all things" (Cheung 2008). Mana tangata is linked inherently to whakapapa to define one's self (Keelan, 2015) and ensures a support network surrounds the child. Whakapapa confirms kinship, guarantees access to resources and provides guidance through kawa and tikanga. It legitimises participation in hapu affairs and gives an individual the right to say "I am Māori" (Mead, 2003). The Māori Affairs Act 1953 defined Māori as being "a person intermediate in blood between half-castes and persons of pure descent...”. However, from 1974 the legal definition of being Māori broadened to include whakapapa, genealogical descent of Māori ancestry no matter how far removed, see The Treaty of Waitangi Act 1985 and Te Ture Whenua Māori Act 1993 (Coates, 2008). This is important regarding being able to situate yourself and enjoying a sense of belonging that mana whenua gives (Keelan, 2015).

Tūrangawaewae or place where one has a right to stand. Pere (1997) writes about Tūrangawaewae where the roots are deep a person can move into any context knowing they can stand anywhere because their identity is secure. Pere (1997) continues to say it is important for every child to know where 
they come from so they can enjoy greater control of their life. Having just completed an internal evaluation on affirmation of identity, language and culture the parents' voice strongly advocating for visibility and recognition of their cultures and home language, with parents offering to involve themselves in the learning programme or pointed to their child/ren as experts who were ready and able to lead teachers learning. This is particularly valuable when to our amazement we discovered 24 different cultures and ethnicities among our children and their families. If we included staff ethnicities that number increased to 28. Pere (1997) said the education of children around whakapapa especially for Māori children should be about their history, genealogy, legends, proverbs, songs, obligations and responsibilities towards their tribe. In the findings of the internal evaluation, the teachers' voices advocated for a deeper level of engagement in children's languages and cultures all throughout the year and not just for a week. They saw the necessity for professional development and realised the wealth of access to cultural experts from amongst the staff and community of parents and whānau. Lack of confidence to kōrero Māori and limited understanding of tikanga explained a teacher's deficit practice. The revised curriculum becomes a valuable tool in providing positive outcomes for teachers and children because of the many examples of tikanga, whakatauki as well as Māori models of assessing holistic development and learning. When teachers asked themselves what more could be done they sprang into action immediately with the following responses; revising the 'All about me' sheet to focus on parent and children's voices, using colleagues and whānau as cultural experts, gathering information on the ethnicities of children and their families, and organising a pōwhiri for new children and their whānau. The infant teachers set about making a book for all the cultures of the centre with images around transport, housing, clothing and food. We are working consistently in responding to parents' needs to see and hear their culture, so their child's identity is affirmed. 


\section{Conclusion}

He Tamaiti Tapu a principle-based model of well-being for children is founded on Māori knowledge, values, principles, tacit knowledge and lived experiences. Each principle of mana, mauri, wairua and whakapapa are intrinsically connected and support and uphold each other. Often it has been difficult to separate these principles as they cross over, through and around each other intimating that when these four principles are in play and are ensconced in my practice, there is a deep abiding sense of power, love and respect at the heart of all things. I specifically surrounded the child and these principles within mana atua, mana tangata, and mana whenua as they act as guardians of identity. As a model of well-being, this would easily translate to any age or culture. It is a proven model from where I situate my practice and have done so throughout my life even before I became a qualified registered early childhood teacher. Babies and young children have always been held in high regard in my family. We have fought each other for opportunities to feed, put to sleep, and even change the baby's nappy. Is it any wonder I find myself in this profession of early childhood educator? 


\section{References}

Barlow, C. (2007). Tikanga whakaaro: Key concepts in Māori culture. Victoria, Australia: Oxford University Press.

Brain Wave Trust. (2015)

Cheung, M. (2008). The reductionist - holistic worldview dilemma. MAI Review, (3), Research Note 5.

Coates, N. Who are The Indigenous Peoples of Canada and New Zealand? Journal of South Pacific Law, 12(1), 2008, 49-55 http://www.paclii.org/journals/fJSPL/vol12no1/pdf/coates.pdf

Education Review Office (1998). The use of Te Whäriki in early childhood centres. Retrieved from http://www.ero.govt.nz/ero

Education Review Office. (2010). Success for Māori children in early childhood services: Good practice. Retrieved from http:/ / www.ero.govt.nz/National-Reports/Success-for-MaoriChildren-in-Early-Childhood-Services-Good-Practice-May-2010

Gerber, M. (1998). Seeing babies with new eyes. Retrieved https://www.magdagerber.org/

Hemara, W. (2000). Mãori pedagogies: A view from the literature. Wellington: New Zealand Council for Educational Research.

Keelan, R. (2015). A Māori perspective on well-being. He Kupu vol.4, n.o.2.

Māori Affairs Act 1953.

Marsden, M. (2003). The woven universe: Selected writings of Rev. Mãori Marsden. Masterton, New Zealand: The Estate of Rev. Māori Marsden

Mead, H. (2003). Tikanga Māori: Living by Māori values. Wellington, New Zealand: Huia.

Ministry of Education. (1996). Te Whāriki, he whāriki mātauranga mō ngā mokopuna o Aotearoa: Early childhood curriculum. Wellington, New Zealand: Learning Media.

Ministry of Education. (2009). Te whatu pokeka. Kaupapa Maori assessment for learning. Early childhood exemplars. Wellington, New Zealand: Learning Media.

Ministry of Education. (2017). Te Whāriki, he whāriki mātauranga mō ngā mokopuna o Aotearoa: Early childhood curriculum. Wellington, New Zealand: Learning Media.

Parentingworx. (2009). Emmi Pikler's guiding principles. Retrieved https://www.parentingworx.co.nz/fantastic-reading/emmipiklers-8-guiding-principles /

Paul-Burke, K. (2011). Kaitiakitanga, towards a sustainable future: Mātauranga Māori and baseline surveys of tāōnga species in the rohe moana of Ngāti Awa (Unpublished Master's thesis). Te Whare Wānanga o Awanuiārangi, Whakatāne, New Zealand.

Pere, R. (1997.) Te Wheke: A celebration of infinite wisdom. Gisborne, New Zealand: Ao Ako Global Learning.

Rameka, L. (2015). Te ira tangata: The spiritual spark of the child. He Kupu: vol. 4, n.o.2. $2015 . \quad$ Retrieved 
https://www.hekupu.ac.nz/article/te-ira-atua-spiritual-sparkchild

Reedy, T. (2003). Toku rangatiratanga na te mana-matauranga "Knowledge and power set me free...". In J. Nuttall (Ed.), Weaving te whäriki (pp. 51-77). Wellington: New Zealand Council for Educational Research.

Ritchie, J. (2003). Bicultural development within an early childhood teacher education programme. International Journal of Early Years Education, 11 (1), 43-56.

Ritchie, J. (2010). Being sociocultural in early childhood education practice in Aotearoa. Early Childhood Folio 14.

Te Ture Whenua Māori Act 1993. 